\title{
モデュラー・コオーディネーションによる アパートの標準設計の展開の方法
}

（との 1）モデュラー・コオーディネーションの意味について

\begin{tabular}{|c|c|c|c|c|c|c|c|c|}
\hline 会員 & ○田 & 辺 & 員 & 人* & 正会員 & 池 & 田 & 武 邦 ${ }^{* *}$ \\
\hline 同 & 㳆 & 辺 & & 陽 ${ }^{* * *}$ & 同 & 内 & 田 & 祥 哉 ${ }^{* * *}$ \\
\hline 同 & & 谷 & 幸 & 夫 $^{* * * *}$ & 同 & 金 & 子 & 勇次郎 ${ }^{* * *}$ \\
\hline 同 & & H & & 玄 $^{* * * * * *}$ & & & & \\
\hline
\end{tabular}

\section{まえがき}

最近比較的短汃期間任 (1956 58 年) modular coordination への機運がたかまり、その実施のための準備 活動が 行政機関・学界・業界の各方面でなされてい る。しかし関係各界の modular co-ordination 亿対す る期待のもち方、招よび module そのるのと対する理 解のしかたに、未宅相当のズレがあることは明らかであ り、それらが相互淍整され、現害の客観的な条件沉し たがつて統一されることは、co-ordination の速やかな 垟成のためにる、またより良い module を完成するた めにる、必要なことである。

ここでは、modular co-ordination という現代の国際 的な概念がどのような背景のるとと形成されたかを概観 し、それが単純な経済行為でなく、建築活動と招ける文 化的価值の創造につよく影響する点沉ついて考察したい と思う。

\section{Modular Co-ordination の沿革}

“Module” の概念は古代ギリシャの建築術のなかで 用いられ、重要な芸術的意味をるつていた（Vitruvius） 以来、ヨーロッパの建築史上にしばしばこの概念があら われ、特に古典主義的な傾向のつよい時代には建築各部 の幾 何学的なパターンや比例の 規則正しさが、この module の内容として重用された。その後光いに Le Corbusier がある。

1936 年アメリカの Albert F. Bemis は “Cubical Modular Method”を提案し、多くの建築家や建設業者 の支持を得て、1939 年《は American Standard Association を舞台としてその普及にのり出した。(Project A 62)。Bemis 恃美学的な意味で module の使用を提 唱したのではなく、建物招よびその構成材の規格化のた ぬの単純な共通測度単位を設定しょうとしたのである。

\footnotetext{
* 国際建築 ** 山下建築事務所

*并東大 ****東大 ****東大

*****建設省 $* * * * * *$ 川村建設事務所
}

しかしここで、古典建築に㧍ける“"module”の語が借 用され、この新しい用法による “実用的” 測度単位をる つて“module”と呼んだのである。

この Bemis の module は、特定の一個の建築㹸対 して設定されるるのでなく、多数個の建筑に共通して用 いられることを予想した。ここ沈 “Modular Co-ordination”の考方方が生れたのである（古典茟築術に括い ては、module 恃個々の建物ごとに設定された)。

Modular Co-ordination とは、建築生産招よび建築 材料（主と乙て componentの形で）生産に括いて、共 通の相対的測度単位（公定尺度に対して）を用いて寸法 調整 (dimensional co-ordination) をすることである、 と定義することができる。

上記のようそ、modular co-ordination の概念が最初 に発展したのは二次大戦直前のアメリカに括いてであ る。ヨーロッパでは、1940年代に入つて戦争のために技 術交化の交流が停止していたが、コルビュジエなどフラ ンスの建築家によつてその概念が発展させられた。戦後 1945 年から 48 年にかけては、スカンジナビヤ諸国でる 同様な着想が普及した。多くの国々で同時並行して、 modular co-ordination が建設工費の低減に役立つであ ろうという期待のもとに研究が進められた。

イギリスに括いては、はじめドイツの戦時住宅規格に 学び、戦後の住宅と学校の大量建設のなかで（特に Hertfordshire 等飞和ける公立学校の進歩的な建設活動の なかで、かなり理論的・契践的に成果があげられた。

アメリカ拉よび西欧諸国の modular co-ordinationの 活動は、1953 年以来継続されている European Productivity Agency の共同研究事業によつて国際的に組織 化されようとしている。

ソヴエト、中国等、社会主義諸国では、多くの場合、 革命とともにメートル制への急激な切りか党が行われ、 その新しい公定尺度の普及とならんで、計画的大量建設 飞不可欠な dimensional co-ordination が矢張り“"module”の概念を意識的飞採用するとと沉つて進められ ている。 


\section{Modular Co-ordination $の$ 経済的意義}

\section{(a) EPA の場合}

現在欧米 13 力国による modular co-ordination の共 同研究を組織している EPA (European Productivity Agency) は、OEEC (Organization for European Economic Co-operation) 亿付属する機関である。

1948 年 4 月、アメリカの主導する “マーシャル”計 画のもとに、欧洲 16 力国は ERP(European Reconstruction Plan) の実施に入つた。これによつて西欧経済 は、アメリカを中心とする一種の共栄圈的組織の一環に 組みこ委れた。（マーシャル・プラン自身忹、単滛済 の分野にとどまらず、これて先立つてトルーマンのギリ シャ・トルコ軍事援助执よびこれに続く北大西洋条約と 相俟つて、政治的认は反共国家群の結合を促がし、軍事 的には反ソ再軍備をすすめるアメリカの基本的対外政策 と不可分に結びくつものであつた)。アメリカは 1948 年 4 月、（経済協力法）に上り対外援助実施機関として ECA「経済協力局」を新設し、中央事務局をワシント ンとパリそ招き、ERP 参加諸国にもとれぞれ駐在使節 を送つた。西欧 16 力国側でる、この援助の受入れ機構 として OEECをパリに設置した。

EPA は 1953 年 5 月に OEEC のもとてつくられた。 その任務は、生産性を向上させることとょつてヨーロッ パの生活水準をたかめ、そのために各国の政府のみなら ず工業・農業・科学的研究の各団体・機関、個人括よび 集団的の企業、公共事業団体等にも働らきかけることで ある。参加各国の国内機関としては、「生産性本部」の如 きるのがそれぞれ組織されている。EPA は「労使協調」 による産業平和の維持と、これによる広義の生産性向上 を重要な目標として特記しているが、同時に、技術的進 歩炕よる本来の学働生産性向上を国際的な規模で果すた めと、種々の事業を行つている。

EPA Kは Building Section があり、その事業とし $\tau$ modular co-ordination の国際共同研究が組織され たのである。(EPA Project No. 174)

«大戦後ヨーロッパでは、社会的飞る文化的にる最も 困難な問題の一つとして住宅問題が横たわつていた。… …多くの国で、大規模な住宅建設計画がたてられ、既に その成果が顕著に表われはじめている。しかしながら、 それらの努力にも拘らずヨーロッパの住宅建設計画は、 その生産コストがもつと引き下げら゙れない限り、完全実
施は望めないということが明らかてなつている。住宅へ の資本投入は非常に重い負担となるので、国内経済の限 界内だけで住宅計画を完遂しょうとすることは殆えど不 可能であろう。現在の住宅建設費でも家梖も高くつき、 一般の人にとつては経済的に無理であるということも、 以上の点関連して注目すべきことがらである。この緊 急な問題を解決する唯一の方法は、今まで手工業的基盤 そしか立つていなかつた住宅建設に、近代的な工業生産 方式と技術とを駆使することである。規格化された建築 構成材の工業生産により、建築費はいくらかでる減らさ れ、従つて家賃の引下げも可能となる。このような建築 生産工業化の基本的条件山、建築構成材規格化の基礎と なるモデュラー・システムの採用である。……

(Report of EPA Project No. 174; Preface by M. Roger Gregoire, Director of the EPA)

以上のような趣旨飞るとずいて、1953 年 11 月に "Productivity and Applied Research Committee" 各国の modular co-ordination の專門家を招集し、研 究計画の立案がはじめられた。1954年 5 月、ProjectNo. 174 がこの committee によつて承認され、研究の第一. 段階に入つた。イギリスの専門家がその原案の作成と、 その後の事務局活動をひきうけている。

研究は二段に分けて行われた。第一段掯（1954～56)

は、参加各国の既往の研究・実施状況の情報蒐集とその 理論面の整理、一般報告書の編集飞宛てられ、その結果 は 1956 年 6 月飞“Modular Co-ordination in Building” という表題を付して公刊された。（邦訳：国際建築1958 年 1 月号特集号)

研究の第 2 段階（1956～58）は、前記のレポートに示 された理論を試作実験洫適用することに宛てられた。こ の実験は、当初の申合せ事項に原則的に従がいながら、 各国別々とれぞれの立場を加味して行ない、 academic な議論だけで注出来ない実践的な検証をすることを主眼 とした。この試作実験では cost の問題はかなり特殊な 問題となるので、専ら技術的な側面について重点が抬か れた。この第 2 段階の研究の結果怯、1958年 9 月飞行わ れる committee の最終討論をへて、レポートとして続 刊される筈である。

第一段階で採用され、第二段階で実験供されている module法、イギリスの“The Modular Number Pattern” と相似した独特の自然数数列をシステムとして用い、10

\begin{tabular}{|c|c|c|c|c|c|c|c|c|c|c|}
\hline & & & & & 1 & & & & & $(\times 10 \mathrm{~cm}$ or $4 \mathrm{inch})$ \\
\hline & & & & 2 & 5 & 3 & & & & \\
\hline & & & 4 & 10 & 6 & 15 & 9 & & & \\
\hline & & 8 & 20 & 12 & 30 & 18 & 45 & 27 & & \\
\hline & 16 & 40 & 24 & 60 & 36 & 90 & 54 & 135 & 81 & \\
\hline 32 & 80 & 48 & 120 & 72 & 180 & 108 & 270 & 162 & 405 & 243 \\
\hline
\end{tabular}


$\mathrm{cm}$ 又壮 4 inch を basic module として用いたもので ある。(表参照)

更にこの module を用いて行う modular planning そ対し、寸法線の押え方和よび構成材の接手の納まり等 そついて原則的な明合せを行つている。

EPA のこの共同作業は、それが企画され実施される 「場」の条件之、企画者および参加諸国の一致した目的 意識とに扣いて、それぞれ著しい特徴をるつている。す なおち、

\section{場の条件については一}

・建築生産の工業化の高度に進んだ、或いは進さ可 能性のある西欧諸国を舞台としていること。

- 国際的であること。

・吹时制の英米両国と、メートル制の大陸諸国とを 含んでいること。

ete.

\section{目的意識については一}

- 場の限定として、住宅問題の解決という具体的且 つ経済的な局面を当面の対象としていること。

・加工建築材料の西欧統一市場の形成を意図してい ること。

- 規格化を通じて design, manufacturing,building の三段階に能率向上をるたらすという、純然たる 技術的、経済的目標に重点を招き、designの芸術 的側面に特に影響を与えるような module の採 用を意図していないこと。 etc.

このような、modular co-ordination を成立させよう とする「場」の性質（客観的条件）と、「目的」の性質 (主観的条件 (との両方に適合するような module が選ば れることが、他のあらゆる場合にる必要である。そして 逆に、この両方の条件の限定のしかたと、その解決のさ れ方とを対照することによつて、特定の modular co. ordination の行為全体の経済的価值あるい恔文化的価值 を評価しろるのである。

EPA の場合、modular co-ordination について直接 的な経済的価值以外のるのを示陖しているのは、報告書 にあらわれる次の点でだけである。

«……設計者は製図室で経済的効率を非常に増すこと ができ……例えば英国では規格ディテールを使うことに よつて材料仕様のための製図の時間は殆えど半分に減つ てしまい、組立工事のための製図をる単純にしてしまう ので、設計上の他の面や研究作業に対して、より多くの 時間をかけることができるようになつたことがわかつて いる。….»(EPA Report; Summary)

EPA Project汇参加したイタリアの Prof. Giusseppe

Ciribini は次のように評価している。

《建築産業の modular co-ordination 関して EPA
が行つている研究作業の価值は、主として彼等のとの 問題に対する realistic な追求のしかたにかかつてい る……… 》《事実彼等は modular co-modular coordination ということを、industrial action の最も 效果的な手段であると考えている……》(“European Productivity" No. 25; Mar-Apr. 1957)

\section{(b) Le Modulor の場合}

前記の EPA の場合のようそ、module 特よびmodular co-ordination 飞対して全く生産面の合理化という経済 的側面にの期待をかけるすのに対して、Le Corbusier の “Le Modulor” の提案のようなるのは、文化的価值 の創造にる特に重点を特いている点で特徴的である。

Le Corbusier は modular co-ordination と彼自身の Le Modulor の場と目的を次のように述べている。

《目的を見失うまい。

世界の生産の「流れ」を調和せしめること。それは 世界的な量産に組織されることだるう。人類の歴史の 中で、これは偉大な事件としていま起りつつあるのだ。 標準化するということは、便宜的なるのへ陥る危険が ある。経済的生産法の寸でに発展ということはあるけ れども。

さらにまた、最少の摩擦による標準化。相互譲渡か らつくられる標準化といつた、うんざりさせられるる のをつくる誤りをさけること。

平凡で、単調で、醜悪である代りに、つねと調和し ていて、変化あり、優美であることを証明され約束さ れた方へ。

それからまた、メートルと呎哳との間にある和解で きない寸法の障害をとりのぞくこと。》

(Le Modulor; 第 4 章。吉阪隆正訳)

Le Corbusier るまた、彼の提案を自身和よび多数の 共鳴者を通じて実験例を蓄積している。

\section{文化的意義}

文化ということを最も広義に解橎すると、「生産・消

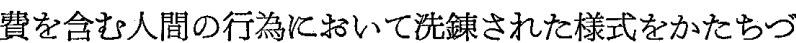
くること」である。すなわら与えられた場の中で特定の 目的を果すために、場と目的との両方の条件を必要且つ 十分に満たすような行為（或い性為の結果）の型をつ くることである。そのような完結した型の成立が意識さ れた場合に心理的な充足感をるたらすと同時に、他に同 様な場と同様な目的が与えられた場合に、この型は直ら 飞範例として直接繰り返し利用することができる。し かしそのような条件がそろうことは稀であり、多少とす 断続的湯の条件と目的の条件とがそれぞれ変化してゆ くから、この場合には、且て成立した「型」は意識的な 修正を経て新しい「型」に発展する。 
文化性は、それが低い次元では単なる経済性や機能性 飞還元し、高次江築かれた場合に法芸術性江転化する。 しかしそのような意味で経済性・機能性と芸術性とは本 来連続したるのであり、相対立するようなるのではな w。

Modular co-ordination は、現在世界的な課題々なつ て招り、近代産業をるつた国々では大なり小なりこの 問題が真剣飞追求されている。そことは種々の相対立す る提案がなされ、また異つた段階での解決が求められ る。しかし“co-ordination”という局面限定すると、 その対象が建築産業であつたり機械産業にまたがつた り、或いは単なる個人の設計活動の範囲にとどまるよう な、場のひろがりの相違があつたとしても、寸法秩序の社 会的規制行為であるという本質はわからない。それ故ど んな種類の module を予想する場合でる co-ordination の方法、手続きとついては、共通の正しい筋道が存在す る筈であつて、co-ordinate の主体となる組織・機関は そのような筋道と対して謙譲でなければならない。その 行為の中にる最も広い意味での交化性を求めたいのであ る。

しかし modular co-ordnation の最大の文化的意義は そこに使用される module そのるのの文化的価值の如 何にかかつてくる。

\section{おわりに}

Modular coordination は現在日本だけでなく、世界 の有力な国々あるいは経済圈がそれぞれ相並んで研究し 実験している段階にある。各国がそれに相当の年数と手 間をかけているのを知るとつけてる、わが国の module 括よび modular co-ordination が安易化求められるべき ではないことが痛感される。日本という特殊な場の条件 と、将来のある段階までを限つての目標とを厳密烧定 することが一切の活動炕先行すべきであり、そのよろな
前提条件の検討を経ずして機械的な模倣や手軽な便宜的 決定がなされることを警戒すべきであるう。そして安定 乙た解決を見出すためには、理論的追求のほか江広範团 な実験検証の手つづきをふむことが大切である。

日本に和いて modular co-ordination を意図する場 合は少くとも次のような諸点溜意する必要があると思 われる。

1. modular co-ordination が計画されてから或る程 度の普及をみるまでとは、相当の時間が経過する あのと考觉なければならない。その間に、国際市 場の条件や、建築産業自体の技術的条件がかなり 変動し発展する䈏であるが、このような面につい てはそれぞれの局面の専門的な研究を通じて、正 しい見通しをたて、その見通しに従つた計画をた てなケればならない。たとえばアジア諸国に括け る市場関係の変化の見通し、建築生産の工業化の 進展の度合などについてである。

2. 日本の伝統的なモデュール制度一卞なわち木割 から発展した和風住宅の文化性に対し、ぞの上う な改革案をたてるとしても、その結果汶対して責 任をるたなければならない。

3. 日本のよろ飞生産の様式の複雑な条件のなかでは co-ordination の起点を何て招き、何が主体とな つて指導するか炕ついて、明確な計画をるつ必要 がある。

4. Modular co-ordination は、単飞寸法関係の規定 だけで成立するるのでなく、建築の計画・生産・ 経営の各面にわたつて多数の副次的な技術的変革 をともなうものであるから、それらの体系的な準 備が当初から予定されなければならない。そのた め㰅当な建設課題一たと光ば公共住宅建設 一を選えで、精密な case study を行うことが 適切である。 